\title{
HUBUNGAN ANTARA KOMPETENSI DAN PENERAPAN SISTEM MANAJEMEN MUTU DENGAN KEPUASAN KERJA KARYAWAN
}

\author{
Supriyatno \\ Universitas Mercu Buana \\ Email: yatno1207@yahoo.co.id
}

\begin{abstract}
This research was conducted to analyze the Competency and System Applied Quality Management ISO 9001: 2000 about Employee Satisfaction Work in Mercu Buana University at Jakarta. A survey method used during this research in which questionnaires were distributed to the respondents. The hypothesis analysis used the technique of simple and multiple regression and followed by the correlation. Using the Computer Program of SPSS (Statistical Product Service and Solution) with $\mathrm{n}=103$ (respondents) and $\mathrm{r}$-tabel $=$ 0,195, the result showed that there was a less influenced between Competency and System Applied Quality Management ISO 9001 : 2000 to the Employee Satisfaction Work either Independent or concurrently. The Determinant Coefficients or Competency and System Applied Quality Management ISO 9001 : 2000 about Employee Satisfaction Work were 0,250 and 0,348. Which means the effects of Competency and System Applied Quality Management ISO 9001 : 2000 about Employee Satisfaction Work were $25 \%$ and $34,8 \%$ and the largely influenced by the factors. The Determinant Coefficients of Competency and System Applied Quality Management ISO 9001: 2000 about Employee Satisfaction Work was 0,420. Which means the effects of Competency and System Applied Quality Management ISO 9001: 2000 concurrently about Employee Satisfaction Work was $42 \%$ and the $58 \%$ Influenced by other factors.
\end{abstract}

Keyword: Employee Satisfaction Work, Competency, and System Applied Quality Management ISO 9001: 2000

\begin{abstract}
Abstrak: Penelitian ini dilakukan untuk menganalisis Kompetensi dan Sistem Manajemen Mutu Terapan ISO 9001: 2000 tentang Kepuasan Karyawan Bekerja di Universitas Mercu Buana di Jakarta. Sebuah metode survei yang digunakan selama penelitian ini dimana kuesioner dibagikan kepada responden. Analisis hipotesis digunakan teknik regresi sederhana dan berganda dan dilanjutkan dengan korelasi. Menggunakan Program Komputer SPSS (Statistical Layanan Produk dan Solusi) dengan $n=103$ (responden) dan r-tabel $=0.195$, hasilnya menunjukkan bahwa ada kurang dipengaruhi antara Kompetensi dan Sistem Terapan Manajemen Mutu ISO 9001: 2000 untuk Karyawan kepuasan Kerja baik Independent atau bersamaan. The Determinan Koefisien atau Kompetensi dan Sistem Terapan Manajemen Mutu ISO 9001: 2000 tentang Pegawai Kerja Kepuasan yang 0250 dan 0348. Yang berarti efek Kompetensi dan Sistem Terapan Manajemen Mutu ISO 9001: 2000 tentang Pegawai Kerja Kepuasan adalah 25\% dan 34,8\% dan sebagian besar dipengaruhi oleh faktor-faktor. Koefisien Kompetensi dan Sistem Terapan Manajemen Mutu ISO 9001: 2000 tentang Pegawai Kerja Kepuasan adalah 0.420. Yang berarti efek Kompetensi dan Sistem Terapan Manajemen Mutu ISO 9001: 2000 secara bersamaan sekitar Karyawan Kerja Kepuasan adalah 42\% dan 58\% Dipengaruhi oleh faktor lain.
\end{abstract}

Kata Kunci: Kepuasan Karyawan Kerja, Kompetensi, dan Sistem Terapan Manajemen 


\section{PENDAHULUAN}

Persaingan lembaga pendidikan untuk menjadi yang terbaik semakin ketat. Hal ini dapat dilihat dari perbaikan-perbaikan yang mereka lakukan dalam segala aspek guna dapat dianggap sebagal lembaga pendidikan yang dapat menghasilkan output yang handal serta berkualitas. Namun untuk dapat menghasilkan output yang berkualitas, maka diperlukan sumber daya manusia yang handal dan berkualitas serta mampu menciptakan keunggulan kompetitif.

Untuk meningkatkan daya saing lembaga pendidikan agar dapat bertahan dalam bisnis ke depan diperlukan penataan manajemen yang berkesinambungan. Penerapan Sistem Manajemen Mutu ISO 9001:2000 sebagai sistem manajemen mutu dalam proses bekerja akan sangat membantu daya saing hasil produk atau Jasa. ISO 9001:2000 sebagai standar intemasional untuk sistem manajemen mutu mempunyai prinsip-prinsip yang menekankan komitmen manajemen untuk mencapai kesempurnaan jasa pelayanan. ISO 9001:2000 adalah standar yang berisi persyaratan untuk sistem manajemen mutu, di mana persyaratan ini dapat diterapkan di semua jenis dan ukuran organisasi, serta apapun produknya. ISO 9001:2000 mempunyai pemeran utama pada manajemen mutu, yang dimaksudkan agar organisasi dapat: (a) memenuhi persyaratan rnutu dari pelanggan, (b) memenuhi peraturan pemerintah yang terkait, (c) meningkatkan kepuasan pelanggan, (d) mencapai peningkatan kinerja secara berkesinambungan sesuai tujuannya.

Secara umum menajemen mutu dapat didefinisikan sebagai upaya sistematis melalui fungsi perencanaan, pelaksanaan, pemeriksaan, pengendalian, pelatihan, audit internal, serta tindak lanjut terhadap semua unsur yang ada dalam organisasi atau perusahaan untuk merealisasikan komitmen, kebijakan, dan sasaran mutu yang telah ditetapkan dalam rangka memberikan rasa puas terhadap pelanggan. Untuk mendapatkan karyawan dan mempertahankan karyawan yang memiliki kemampuan yang tinggi, tidak terlepas dari upaya lembaga pendidikan tersebut dalam memberikan kepuasan kerja yang memadai dan tentunya kompetitif dengan lembaga pendidikan yang lain yang sejenis, sehingga diharapkan karyawan mau meningkatkan kinerjanya dan tujuan lembaga pendidikan dapat tercapai secara optimal serta mampu memenangkan persaingan bisnis.

Sebagai lembaga pendidikan yang mengkhususkan pada pendidikan tinggi yang akan berusia 23 tahun Oktober nanti, Universitas Mercu Buana merupakan salah satu lembaga pendidikan yang turut berperan serta dalam menghasilkan lulusan yang berkualitas. Sebagai bentuk peningkatan mutu akademik terus menerus guna memberikan pelayanan yang terbalk dan memuaskan, terhltung sejak tanggal 4 Oktober 2005 Universitas Mercu Buana telah memperoleh ISO 9001:2000. Untuk dapat bertahan dalam berbagai situasi dan perkembangan jaman, Universitas Mercu Buana harus dapat meningkatkan kompetensi karyawannya serta menerapkan Sistem Manajemen Mutu ISO 9001:2000 dengan baik.

Berdasarkan uraian tersebut di atas, maka yang menjadi rumusan masalah dalam penelitian ini antara lain: (a) Apakah terdapat hubungan antara Kompetensi dengan Kepuasan, Kerja Karyawan Universitas Mercu Buana ?, (b) Apakah terdapat hubungan antara Penerapan Sistem Manajemen Muru ISO 9001:2000 dengan Kepuasan Kerja Karyawan Universitas Mercu Buana?, (c) Apakah terdapat hubungan antara Kompetensi dan Penerapan Sistem Manajemen Mutu ISO 9001:2000 dengan Kepuasan Kerja Karyawan Universitas Mercu Buana ?. Penelitian ini juga bertujuan: (a) Untuk mengetahui kondisi kompetensi karyawan dalam mencapai penyelesaian tugas dan tanggung 
jawabnya di Universitas Mercu Buana, (b) Untuk mengetahui penerapan sistem manajemen mutu ISO 9001:2000 di Universitas Mercu Buana, (c) Untuk mengetahui kepuasan kerja yang dihubungkan dengan kompetensi dan penerapan sistem manajemen mutu ISO 9001:2000 di Universitas Mercu Buana.

\section{KAJIAN TEORI}

Kompetensi. Menurut Robert L. Mathis dan John H, yang dimaksud dengan kompetensi adalah karakteristik dasar yang dapat dihubungkan dengan peningkatan kinerja individu atau tim. Pengelompokan kompetensi terdiri dari pengetahuan (knowledge), ketrampilan (skills) dan kemampuan (kecakapan). (Mathis \& Jackson, 2001:238). Sedangkan menurut Soekidjo, Kualitas Sumber Daya Manusia menyangkut dua aspek, yakni aspek fisik (kualitas fisik) dan aspek non fisik yang menyangkut pekerja, berpikir dan ketrampilan lain. Aspek kualitas Sumber Daya Manusia sebagai individu tersebut oleh ahli disebut sebagai kompetensi dan hal ini dikaitkan dengan lingkungan kerja. (Notoatmodjo, 2003). Selanjutnya menurut Jiwo Wungu Hartanto Brotoharsodjo dalam Merit Sistem, "kompetensi adalah segenap kemampuan dan hasrat atau kesediaan untuk berprilaku tertentu yang akan menghasilkan performance". (Brotoharsojo, 2003:51). Terdapat tiga faktor yang membentuk kompetensi menurut Jiwo Wungsu (Brotoharsojo, 2003) yaitu : (a) Kemampuan (Ability), yaitu segenap kemampuan, pengetahuan serta penguasaan pegawai atas teknis pelaksanaan tugas-tugas jabatannya, (b) Motivasi (Motivation), yaitu taraf kesediaan, hasrat atau dorongan seseorang untuk melakukan tlndakan atau berprilaku tertentu yang menunjang pencapalan prestasi kerja tinggi, (c) Potensi (Potency), yaitu gabungan dari segenap kemampuan dan kesediaan karyawan yang belum tampil karena masih terpendam yang merupakan sumber energi bagi tampilnya ability dan motivasi seseorang. Kompetensi merupakan karakter dasar orang yang mengindikasikan cara berprilaku atau berpikir, yang berlaku dalam cakupan situasi yang sangat luas dan bertahan untuk waktu yang lama. Ada lima jenis karakteristik kompetensi (R. Palan Ph.d, 2007:9), yaitu: (1) Pengetahuan, merujuk pada infonmasi dan hasil pembelajaran, seperti pengetahuan seseorang ahli bedah tentang anatomi manusia, (2) Ketrampilan, keahlian merujuk pada kemampuan seseorang untuk melakukan suatu kegiatan, (3) Konsep diri dan nilai-nilai merujuk pada sikap, nilai-nilai dan citra diri seseorang, (4) Karakteristik pribadi merujuk pada karakteristik fisik dan konsistensi tanggapan terfladapsituasi atau lnformasi, (5) Motif merupakan emosi, hasrat, kebutuhan psikologis, atau dorongan-dorongan lain yang memicu tindakan.

Prinsip Manajemen Mutu. Delapan prinsip menajemen mutu yang akan berintegrasi pada klausul-klausul ISO 9001 : 2000 antara sebagai berikut (Suardi, 2004): (1) Fokus pada pelanggan, pelanggan adalah kunci untuk meraih keuntungan. Kelangsungan hidup perusahaan/ organisasi sangat ditentukan bagaimana pandangan pelanggan terhadap organisasi tersebut. Oleh karena itu, organisasi harus mengerti keinginan pelanggan sekarang dan masa depan dengan berusaha memenuhi persyaratan pelanggan dan berusaha melebihi harapan pelanggan, (2) Kepemimpinan, Kinerja pemimpin (leader) adalah memiliki kemampuan untuk menciptakan visi yang mengandung kewajiban untuk mewujudkannya, yang membawa orang lain ke tempat yang baru, yang memiliki kemampuan untuk mewujudkan visinya ke dalam kenyataan. Pemimpin juga harus membuat tujuan perusahaan dengan menciptakan dan memelihara lingkungan internal 
yang membuat semua personel terlibat dalam pencapaian sasaran perusahaan, (3) Keterlibatan personel, adalah dasar yang dipentingkan dalam prinsip manajemen mutu. Hal ini dapat dilakukan dengan cara memampukan dan memberikan kesempatan kepada personel untuk merencanakan, menerapkan rencana, dan mengendalikan rencana pekerjaan yang menjadi tanggung jawab atas kelompoknya. Dengan adanya keterllbatan personel secara menyeluruh, maka akan menghasilkan rasa memiliki dan tanggung jawab dalam memecahkan masalah. Hal lni akan memicu karyawan untuk aktif dalam melihat peluang untuk peningkatan, kompetensi, pengetahuan dan pengalaman, (4) Pendekatan proses, Standar internasional ISO mengembangkan pemakaian pendekatan proses (process approach) pada masa pembuatan, penerapan, dan peningkatan sistem manajemen mutu yang efektif. Proses dalam ISO 9000:2000 didefinisikan sebagai kumpulan aktifitas yang saling berhubungan/mempengaruhi, di mana berubahnya input (material, persyaratan, peralatan, instruksi) menjadi out put (barang atau jasa) (Suardi, 2004), (5) Pendekatan sistem untuk manajemen, adalah kumpulan dari pendekatan proses. Pendekatan sistem untuk manajemen didefinisikan sebagai pengidentifikasian, pemahaman, dan pengelolaan sistem dari proses yang saling terkait untuk pencapaian dan peningkatan sasaran perusahaan dengan efektif dan efesien (Suardi, 2004), (6) Peningkatan berkesinambungan, harus menjadi sasaran tetap perusahaan, sesuatu yang berbeda jika dibandingkan pada ISO edisi 1994, yang didasari pada continual improvement, setelah dilakukan peningkatan pertama kali, maka sebelum ditingkatkan terlebih dahulu dilakukan stabilisasi. Bila stabilisasi sudah berjalan, baru dilanjutkan dengan meningkatkan standar. Hanya setelah suatu standar ditetapkan dan distabilkan, kita dapat melanjutkan ke tingkatan selanjutnya dan hal ini dilakukan terus menerus, (7) Pembuatan keputusan berdasarkan fakta, Keputusan yang efektif adalah keputusan yang berdasarkan data dan informasi yang dapat dipertanggungjawabkan, (8) Pendekatan berkesinambungan, Organisasi dan pemasoknya adalah saling tergantung dan merupakan hubungan yang saling menguntungkan dalam meningkatkan kemampuan keduanya dalam memberikan nilai.

Manajemen Mutu ISO 9001:2000. Standar ISO 9001:2000 adalah suatu standar internasional untuk sistem manajemen mutu. ISO 9001:2000 merincikan persyaratan sistem manajemen mutu di mana organisasi perlu menunjukan kemampuannya untuk menyediakan produk yang memenuhl persyaratan pelanggan dan peraturan yang berlaku dan bertujuan meningkatkan kepuasan pelanggan. (ISO 9000:2000). Standar ISO dikeluarkan oleh International Organization for Standarzation. Organisasi Internasional untuk standarisasi yang berdiri pada tahun 1946 dan berkantor pusat di Jenewa Swiss, ini merupakan organisasi nirlaba yang beranggotakan negara, yang sampai saat ini telah mencapai lebih dari 84 negara dan mendapatkan dana dari iuran anggota dan hasil penjualan standar, Pekerjaan penyiapan standar disusun dan dikembangkan dan diperbaiki oleh sebuah Technical Committee (TC). Komite ini dikenal dengan nama ISO/TC 176 beranggotakan 41 negara dan 22 negara sebagai pengamat. (Huyink \& Westover: 6).

Menurut Gaspersz, "ISO 9001:2000 adalah merupakan suatu standar internasional untuk sistem manajemen mutu. Sedangkan sistem manajemen mutu sendiri adalah struktur organisasi, tanggung jawab, prosedur-prosedur, proses-proses, dan sumber daya untuk penerapan manajemen mutu. Suatu sistem manajemen mutu merupakan sekumpulan prosedur terdokumentasi dan praktek-praktek standar untuk manajemen sistem yang bertujuan menjamin kesesuaian dari suatu proses dan produk (barang dan atau jasa) 
terhadap kebutuhan atau persyaratan tertentu. Kebutuhan atau persyaratan itu ditentukan atau dispesifikasikan oleh pelanggan dan organisasi. (Gaspersz, 2005:10).

Sistem manajemen mutu mendefinisikan bagaimana organisasi menerapkan praktekpraktek manajemen mutu secara konsisten untuk memenuhi kebutuhan pelanggan dan pasar. Masih menurut Gaspers (2005) menyatakan bahwa sistem manajemen mutu mencakup suatu lingkup yang luas dari aktifitas-aktifitas dalam organisasi modern.

Landasan Sistem Manajemen Mutu ISO 9001-2000. Sistem manajemen mutu disusun berlandaskan ketentuan yang bertujuan untuk menaikan/menjaga kualitas hasil produk/jasa melalui tahapan proses yang benar, terukur, dan telah ditetapkan. Menurut Suardi (2001), salah satu dari landasan yang menentukan adalah bagaimana keterlibatan Sumber Daya Manusia yang mampu menerapkan dan memelihara sistem manajemen mutu dan terus menerus dapat memelihara keefektifannya untuk kepuasan pelanggan. Sumber daya yang terlibat dalam mutu produk/jasa harus mempunyai kemampuan atas dasar pendidikan, pelatihan, ketrampilan, dan pengalaman yang sesuai. ISO 9001:2000 menyatakan salah satu prinsip manajemen mutu untuk dapat memperbaiki kinerja adalah keterlibatan Sumber Daya Manusia (orang). Keterlibatannya adalah mencakup: (a) Orangorang yang selalu mengevaluasi kinerjanya, hubungannya dengan organisasi (bukan pribadi), (b) Orang-orang yang merasa memiliki, (c) Orang-orang yang mempunyai rasa tanggung jawab terhadap masalah-masalah yang dihadapi, (d) Orang-orang yang secara terbuka dan bebas mendiskusikan masalah-masalah, pengalaman-pengalaman dan isu-isu yang berkembang, (e) Orang-orang yang memahami pentingnya kontribusi mereka dalam organisasi, (f) Orang-orang yang mampu mengidentifikasi kendala-kendala penghambat kinerja mereka.

Manfaat Penerapan Sistem Manajemen Mutu ISO 9001:2000. Beberapa alasan perusahaan memutuskan menerapkan ISO 9001:2000, sebagaimana hasil survey yang dilakukan Lloyd's Register Quality Assurance Ltd. (LRQA) di antaranya adalah:

Tabel 1. Alasan penerapan ISO 9001:2000

\begin{tabular}{ll}
\hline Alasan & $(\%)$ \\
\hline Bertahan dalam bisnis & $81 \%$ \\
Mengantisipasi permintaan Pelanggan & $73 \%$ \\
Memperbaiki pelayanan pelanggan & $70 \%$ \\
Mempertahankan/Meningkatkan pangsa pasar & $78 \%$ \\
Meningkatkan efesiensi & $70 \%$ \\
Keuntungan pemasaran & $68 \%$ \\
Menjadi ujung tombak pasar lnternasional & $35 \%$
\end{tabular}

Sumber: LRQA Centre, 2000

Hasil survey yang sama menunjukan bahwa manfaat dan keuntungan yang diperoleh dari penerapan ISO 9001:2000 terangkum dalam tabel berikut ini: 
Tabel 2. Manfaat dan Keuntungan Penerapan ISO 9001:2000

\begin{tabular}{|c|c|}
\hline Manfaat dan keuntungan & $(\mathrm{o} / \mathrm{o})$ \\
\hline Peningkatan kontrol pengelolaan & $86 \%$ \\
\hline Peningkatan pelayanan pelanggan & $73 \%$ \\
\hline Konsistensi di dalam organlsasl & $73 \%$ \\
\hline 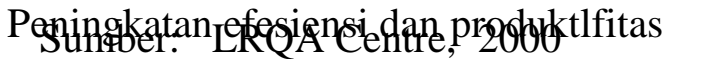 & $69 \%$ \\
\hline Pengurangan limbah & $53 \%$ \\
\hline Peningkatan motivasi pegawai & $50 \%$ \\
\hline Pengurangan biaya & $40 \%$ \\
\hline Peningkatan kesadaran terhadap masalah & $3 \%$ \\
\hline Lainnya & $15 \%$ \\
\hline
\end{tabular}

Kepuasan Kerja Karyawan. Menurut Newstrom dan David (2002:208) dalam buku Human Behaviour at World: Organizational Behaviour, definisi dari kepuasan kerja adalah sikap karyawan dalam menyukai atau tidak menyukai pekerjaannya. Kepuasan kerja itu dinyatakan sebagai besarnya kesesuaian antara harapan yang ingin diperoleh seseorang dengan pekerjaannya dan penghargaan yang ingin didapat dari penilaian terhadap hasil kerjaannya. Menurut Stephen Robbin dalam Perilaku Organisasi (2001:184) menyatakan bahwa: Kepuasan kerja berkaitan dengan sikap umum individu terhadap pekerjaannya, sedangkan Fred Luthans mengungkapkan dalam bukunya Organization Behaviour (2002:230) menyatakan bahwa kepuasan kerja merupakan hasil dan persepsi karyawan, yang menunjukan seberapa baik pekerjaan mereka memberikan hal-hal yang dipandang sebagai sesuatu yang penting. Dengan demikian, kepuasan kerja merupakan sikap umum karyawan terhadap pekerjaannya berdasarkan pandangan dan perasaan karyawan yang menyenangkan atau tidak menyenangkan yang dimunculkan dalam bentuk moral kerja dan disiplin kerjanya yang pada gilirannya menciptakan peningkatan kinerja karyawan. Kepuasan kerja mengarahkan seseorang untuk berkinerja ke arah yang lebih baik dan sebaliknya ketidakpuasan akan menurunkan kinerja karyawan.

Kerangka Berfikir. Bila melihat persepsi dari dinamika organisasi modern baik yang bergerak dalam bidang industri maupun jasa, keunggulan sumber daya manusia menjadi bagian yang mewujudkan eksistensi organisasi. Seorang pekerja/karyawan akan dinyatakan berkinerja tinggi jika kemampuan dan/atau kompetensi yang dimilikinya sesuai dengan kemampuan/kompetensi yang dituntut oleh pekerjaan/jabatannya. Sebaiknya kinerja seorang karyawan dinyatakan rendah jika kemampuan/kompetensi yang dimililkinya tidak sesuai dengan kemampuan/kompetensi yang dituntu oleh pekerjaan/Jabatan. Kompetensi di dalam organisasi dapat diperoleh melalui saluran formal dan informal, pemikaran informasi yang lancar dapat membantu organisasi dalam merespon perubahan kerja, meningkatkan efesiensi, dapat membangun mental karyawan, dan dapat meningkatkan kepuasan kerja karyawan. 
Atas dasar hal tersebut di atas penulis melihat bahwa kompetensi yang ada saat ini, dan penerapan sistem manajemen mutu ISO 9001:2000, akankah ada hubungannya dengan kepuasan kerja karyawan.

Hipotesis. Dalam penelitin ini, maka dibuat hipotesis-hipotesis sebagai berikut:

Hipotesis I : Terdapat hubungan antara kornpetensl dengan kepuasan kerja karyawan Univeristas Mercu Buana.

Hipotesis II : Terdapat hubungan antara penerapan sistem manajemen mutu ISO 9001:2000 dengan kepuasan kerja karyawan Univerlstas Mercu Buana.

Hipotesis III : Terdapat hubungan antara kompetensi dan penerapan sistem manajemen mutu ISO 9001:2000 dengan kepuasan kerja karyawan Univerlstas Mercu Buana

\section{METODE}

Metode penelitian menggunakan metode survey eksplanasl (an explanative survey) dengan paradigma studi assosiatif kausalitas (a cousalitatif associations study paradigma) dan menggunakan teknik analisis data kuantitatif (a quantitative data analysis technique). Data yang diperlukan sebagai pendukung dalam penelitian ini yaitu data primer yang diperoleh melalui pengumpulan data di lapangan dengan teknik pengumpulan data melalui kuisioner, yaitu dengan mengirimkan dan menyebar daftar pertanyaan untuk mengumpulkan data dari populasi atau responden yang terlibat dengan materi penelitian ini. Kemudian hasil yang diperoleh melalui metode penelitian tersebut dituangkan ke dalam bentuk statistik dengan hubungan sebab akibat antara varlabel bebas dengan variabel terikat.

Obyek yang menjadi kajian dalam penelitian ini adalah karyawan yang terdapat dalam struktur organisasi pada perusahaan X, perhatian obyek penelitian ini adalah pada karyawan yang memiliki tugas sebagai staf administrasi, kepala sub bagian dan kepala bagian pada Universitas Mercu Buana di Jakarta yang mempunyai populasi karyawan sekitar 143 karyawan.

Tabel 3. Populasi Responden

\begin{tabular}{clc}
\hline No & \multicolumn{1}{c}{ Pendidikan } & Jumlah \\
\hline 1. & SLTA & 75 \\
2. & Diploma III (DIII) & 11 \\
3. & Sarjana Strata 1 (S1) & 47 \\
4 & SarianaStrata 2 (S2) & 10 \\
& Jumlah & 143 \\
\hline
\end{tabular}

Strmber : Eira Sumber Daya Manusla Universitas Mercu Buana

Dalam penelitian ini penulis menggunakan metode acak sederhana (simple random sampling) yaitu suatu cara mengambil sampel yang representative dari populasi tanpa memperhatikan strata (tingkatan) dalam anggota populasi tersebut. Pengambilan sampel ini harus dilakukan sedemikian rupa sehingga diperoleh sample-sampel yang benar-benar dapat mewakili dan dapat menggambarkan keadaan populasi yang sebenarnya. 
Variabel dalam penelitian ini adalah terdiri dari satu variable terikat yaitu kepuasan kerja karyawan (Y) dan dua variable bebas yaitu kompetensi (Xl) dan penerapan sistem manajemen mutu ISO 9001:2000 (X2), maka dapat diuraikan sebagai berikut:

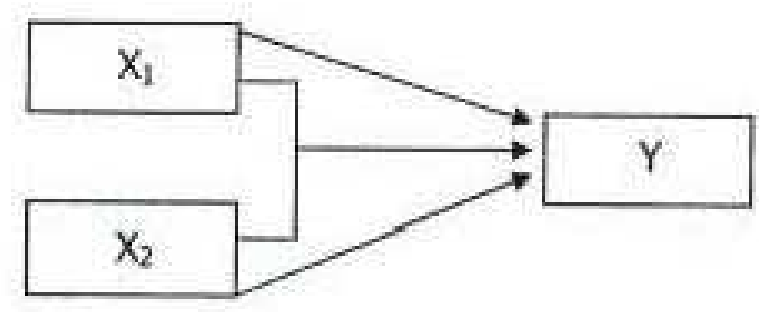

Keterangan: $\quad \mathrm{Y}=$ Kepuasan Kerja Karyawan

$\mathrm{X}_{1}=$ Kompetensi

$\mathrm{X}_{2}=$ Sistem Manajemen Mutu ISO 9001:2000

1. Kornpetensi sebagai variabel bebas $1\left(\mathrm{X}_{1}\right)$ dengan pengukuran interval menggunakan skala likert dengan skor 1-5

2. Penerapan Sistem Manajemen Mutu ISO 9001:2000 sebagal variabel bebas $2\left(X_{2}\right)$ dengan pengukuran Interval menggunakan skala likert dengan skor 1-5

3. Kepuasan Kerja Karyawan sebagai variabel terikat (Y) dengan pengukuran interval menggunakan skala likert dengan skor 1-5

Teknik pengumpulan data yang digunakan dalam penelitian ini menggunakan penelitian lapangan atau metode survey dengan mendistribusikan kuesioner penelitian yang berisikan pernyataan kepada responden yang menjadi wakil populasi dalam penelitian ini. Kuesioner penelitiannya terdiri atas tiga variable yang akan diukur yaitu variabel kompetensi, sistem manajemen mutu ISO 9001:2000 dan kepuasan kerja karyawan dengan lndikatornya masing-masing. Variabel Independent adalah kompetensi $\left(\mathrm{X}_{1}\right)$ dan sistem manajemen mutu ISO 9001:2000 $\left(\mathrm{X}_{2}\right)$, sedangkan variabel dependen adalah kepuasan kerja (Y).

Teknik analisis data yang digunakan dengan pengujian keandalan instrument dengan validitas dan reliablilias instrument penelitian, sehingga akan dapat validitas dan reliabllitas untuk masing-masing instrumen penelitian. Hasil penelitlin yang valid dan reliable menggambarkan data yang sesungguhnya pada obyek yang diteliti, sementara data penelitian yang tidak valid harus di drop dan tidak dipergunakan dalam penelitian. Selanjutnya dilakukan pengujian ulang (retest) terhadap validitas dan reliabilitas sampai hasilnya benar-benar valid dan reliable. Apabila persyaratan tersebut terpenuhi maka data penelitian dapat dipergunakan untuk analisis selanjutnya. Adapun pengujian validitas dan reliabilitas instrument penelitian ini dilakukan pada butir-butir pernyataan yang ada dalam kuesioner untuk masing-masing variabel.

\section{HASIL DAN PEMBAHASAN}

Deskripsi Data. Karakteristik responden berdasarkan jenis kelamin laki-laki berjumlah 77 orang atau 74,8\%, dan responden Perempuan berjumlah 26 orang atau 25,2\%. Karakteristik responden berdasarkan Usia: Usia responden kurang dari 31 tahun berjumlah 35 orang atau $34,8 \%$, usia responden antara $31 \mathrm{~s} / \mathrm{d} 40$ tahun berjumah 41 orang atau $39,8 \%$, dan usia responden di atas 40 tahun berjumlah 27 orang atau 26,2\%. Karakteristik 
responden berdasarkan Pendidikan: Responden yang berpendidikan SMU berjumah 44 orang pemohon atau 42,7\%, responden yang berpendidikan Diploma III berjumlah 13 orang pemohon atau $12,6 \%$, responden yang berpendidikan Strata 1 berjumlah 36 orang atau 35\%, dan responden yang berpendidikan Strata 2 berjumlah 10 orang atau 9,7\%. Karakter responden berdasarkan Masa Kerja: Masa Kerja kurang 1 tahun berjumlah 22 orang atau 21,4\%, masa Kerja 1 s/d 5 tahun berjumlah 29 orang atau 28,2\%, masa kerja 6 s/d 10 tahun berjumlah 39 orang atau 37,9\%, dan masa Kerja lebih dari 11 tahun berjumlah 13 orang atau $12,6 \%$.

Berdasarkan data hasil penelitian yang diperoleh dari pengumpulan data tentang variabel Kepuasan Kerja Karyawan (Y), skor terendah (minimum) adalah 52 dan skor tertinggi (maksimum) adalah 95, dengan range sebesar 43, sedangkan jumlah responden sebanyak 103. Deskripsi data berikutnya berupa distribusi frekwensi (persebaran data) berupa data interval, Hasil pengolahan data SPSS menunjukkan sebanyak 10 buah kelas Interval, hal ini akan memperpanjang langkah-langkah pendeskripsiannya. Untuk mengatasi hal tersebut, telah dilakukan penyederhanaan yang hasilnya sebagaimana ditunjukkan dalam Tabel 4 berikut ini.

Tabel 4. Frekuensi Variabel Kepuasan Kerja Karyawan (Y)

\begin{tabular}{cccc}
\hline No. & Kelas Interval & Frekwensi & Persen \\
\hline 1. & $47,50-52,49$ & 2 & 0,02 \\
2. & $52,50-57,49$ & 2 & 0,02 \\
3. & $57,50-62,49$ & 2 & 0,04 \\
4. & $62,50-67,49$ & 9 & 0,09 \\
5. & $67,50-72,49$ & 18 & 0,17 \\
6. & $72,50-77,49$ & 36 & 0,35 \\
7. & $77,50-82,49$ & 21 & 0.20 \\
8. & $82,50-87,49$ & 4 & 0,04 \\
9. & $87,50-92,49$ & 3 & 0.03 \\
10. & $92,50-97,49$ & 4 & 0,04 \\
& Total & 103 & 1,00 \\
\hline
\end{tabular}

Berdasarkan data hasil penelitian yang diperoleh dari pengumpulan data tentang variabel Kompetensi $\left(\mathrm{X}_{1}\right)$, skor terendah (minimum) adalah 28 dan skor tertinggi (maksimum) adalah 59, dengan range sebesar 31, sedangkan jumlah respondeo sebanyak 103. Deskripsi data berikutnya berupa distribusi frekwensi (persebaran data) berupa data Interval, Hasil pengolahan data SPSS menunjukkan sebanyak 14 buah kelas Interval, hal lni akan memperpanjang langkah-langkah pendeskripsiannya. Untuk mengatasi hal tersebut, telah dilakukan penyederhanaan yang hasilnya sebagaimana ditunjukkan dalam Tabel 4.2, berikut ini. 
Tabel 5. Frekuensi Variabel Kompetensi (X1)

\begin{tabular}{cccc}
\hline No. & Kelas Interval & Frekwensi & Persen \\
\hline I. & $26,26-2875$ & 1 & 0,01 \\
2. & $28,76-3125$ & 1 & 0,01 \\
3. & $31,26-33,75$ & 2 & 0,02 \\
4. & $33,76-36,25$ & 4 & 0,04 \\
5. & $36,26-37,75$ & 4 & 0,04 \\
6. & $38,76-39,25$ & 17 & 0,17 \\
7. & $41,26-43,75$ & 11 & 0,11 \\
8. & $43,76-46,25$ & 26 & 0,25 \\
9. & $46,26-48,75$ & 18 & 0,17 \\
10. & $48,76-51,25$ & 13 & 0,13 \\
11. & $51,26-53,75$ & 5 & 0,05 \\
12. & $53,76-56,25$ & 0 & 000 \\
13. & $56,26-58,75$ & 0 & 000 \\
14. & $58,76-61,25$ & 1 & 0,01 \\
& Total & 103 & 1,00 \\
\hline
\end{tabular}

Berdasarkan data hasil penelitian yang diperoleh dari pengumpulan data tentang variabel Penerapan Sistem Manajemen Mutu ISO 9001 : $2000\left(\mathrm{X}_{2}\right)$, skor terendah (minimum) adalah 75 dan skor tertinggi (maksimum) adalah 120, dengan range sebesar 45, sedangkan jumlah data sebanyak 103. Deskripsi data berikutnya berupa distribusi frekwensi (persebaran data) berupa data interval, Hasil pengolahan data SPSS menunjukkan sebanyak 10 buah kelas Interval, hal ini akan memperpanjang langkahlangkah pendeskripsiannya. Untuk mengatasi hal tersebut, telah dilakukan penyederhanaan yang hasilnya sebagaimana ditunjukkan dalam Tabel 6, berikut ini.

Tabel 6. Frekuensi Variabel Penerapan Sistem Manajemen Mutu ISO 9001 : $2000\left(\mathrm{X}_{2}\right)$

\begin{tabular}{cccc}
\hline No. & Kelas Interval & Frekwensi & Persen \\
\hline 1. & $72,50-77,49$ & 2 & 0,02 \\
2. & $77,50-82,49$ & 4 & 0,04 \\
3. & $82,50-87,49$ & 6 & 0,06 \\
4. & $87,50-92,49$ & 24 & 0,23 \\
5. & $92,50-97,49$ & 28 & 0,27 \\
6. & $97,50-102,49$ & 22 & 0,21 \\
7. & $102,50-107,49$ & 8 & 0,08 \\
\hline
\end{tabular}




\begin{tabular}{cccc}
\hline 8. & $107,50-112,49$ & 4 & 0,04 \\
9. & $112,50-117,49$ & 3 & 0,03 \\
10 & $117,50-122,49$ & 2 & 0,02 \\
& Total & 103 & $1 ; 00$ \\
\hline
\end{tabular}

Pengujian Persyaratan Analisis. Normalitas Data. Uji normalitas pada penelitian ini dilakukan dengan dua cara pertarna yaitu dengan membagi nilai skewness dengan standard error of skewness dan nilai kurtosis dengan standard error of kurtosis pada masing-masing variabel penelitian. Apabila hasilnya berada dibawah \pm 2 , maka data variabel penelitian dinyatakan normal. Maka hasil perhitungan menunjukkan: (1) Variabel Kepuasan Kerja Karyawan (Y) mempunyai skewness - 0,134 dan standard error of skewness 0,238 sedangkan kurtosis 0,887 dan standard error of kurtosis 0,472 , sehlngga diperoleh rasio skewness - 0,5630 dan raslo kurtosis 1,8792. Data tersebut menunjukkan bahwa data penelitian variabel Kepuasan Kerja Karyawan adalah normal, (2) Varlabel Kompetensi $\left(\mathrm{X}_{1}\right)$ mempunyai skewness - 0,438 dan standard error of skewness 0,238 sedangkan kurtosis 0,737 dan standard error of kurtosis 0,472, sehingga diperoleh rasio skewness 1,8403 dan rasio kurtosis 1,5614. Data tersebut menunjukkan bahwa data penelitian variabel Kompetensi adalah normal, (3) Variabel Penerapan Sistem Manajemen Mutu ISO 9001:2000 ( $\left.\mathrm{X}_{2}\right)$ mempunyai skewness 0,434 dan standard error of skewness 0,238 sedangkan kurtosis 0,907 dan standard error of kurtosis 0,472, sehingga diperoleh rasio skewness 1,8235 dan rasio kurtosis 1,9216. Data tersebut menunjukkan bahwa data penelitian variabel Penerapan Sistem Manajemen Mutu ISO 9001:2000 adalah normal. Hasil perhitungan tersebut disajikan dalam tabel dibawah ini.

Tabel 7. Normalitas Data Penelitian

\begin{tabular}{lccc}
\hline \multicolumn{1}{c}{ Variabel } & Rasio Skewness & Rasio Kurtosis & Kesimpulan \\
\hline Kepuasan Kerja & $-0,5630$ & 1,8792 & Normal \\
Karyawan $(\mathrm{Y})$ & & & \\
Kompetensi $\left(\mathrm{X}_{1}\right)$ & $-1,8403$ & 1,5614 & Normal \\
Penerapan Sistem & 1,8235 & 1,9216 & Normal \\
Manajemen Mutu & & & \\
ISO 9001:2000 $\left(\mathrm{X}_{2}\right)$ & & & \\
\hline
\end{tabular}

Homogenitas Varians Data. Ujl homogenitas dilakukan dengan menggunakan Levene Test. Apabila signifikansi > 0,05 maka data penelitian adalah homogen. Uji homogenitas untuk masing-masing variabel dilakukan dengan menggunakan SPSS. Hasil perhitungan disajlkan dalam tabel berikut ini.

Tabel 8. Homogenitas Data Penelitian

\begin{tabular}{lcc}
\hline & $\mathrm{Y}-\mathrm{X}_{1}$ & $\mathrm{Y}-\mathrm{X}_{2}$ \\
\hline Angka Signifikansi & 0,203 & 0,057 \\
\hline
\end{tabular}

Dari Tabel di atas diperoleh angka signifikansi > 0,05, atau data penelitian adalah homogen, sehingga dapat dilakukan analisis selanjutnya. 
Analisis Hipotesis Penelitian. Terdapat Pengaruh Kompetensi $\left(\mathrm{X}_{1}\right)$, terhadap Kepuasan Kerja Karyawan (Y). Dengan menggunakan perhitungan SPSS dapat diperoleh hasil regresi sebagai berikut: $\mathrm{Y}=38,611+0,807 \mathrm{X}_{1}$. Angka regresi tersebut menunjukkan bahwa tanpa Kompetensi, diperoleh angka konstanta Kepuasan Kerja Karyawan sebesar 38,611. Sementara itu setiap penambahan satu satuan Kompetensi akan meningkatkan Kepuasan Kerja Karyawan sebesar 0,807 satuan.

Tabel 9. Persamaan Regresi $Y=26,634+0,094 X_{1}$

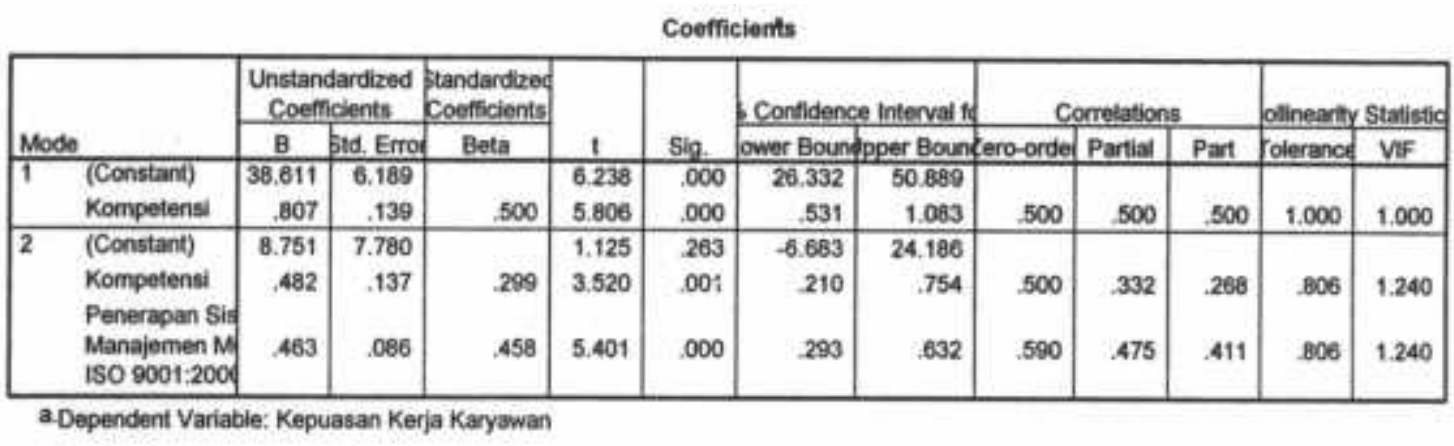

\section{Sumber : Data Diolah}

Perhitungan korelasi dengan program SPSS menghasilkan gambaran seperti tersebut pada tabel di bawah ini.

Tabel 10. Korelasi Kompetensi $\left(\mathrm{X}_{1}\right)$ dengan Kepuasan Kerja Karyawan (Y)

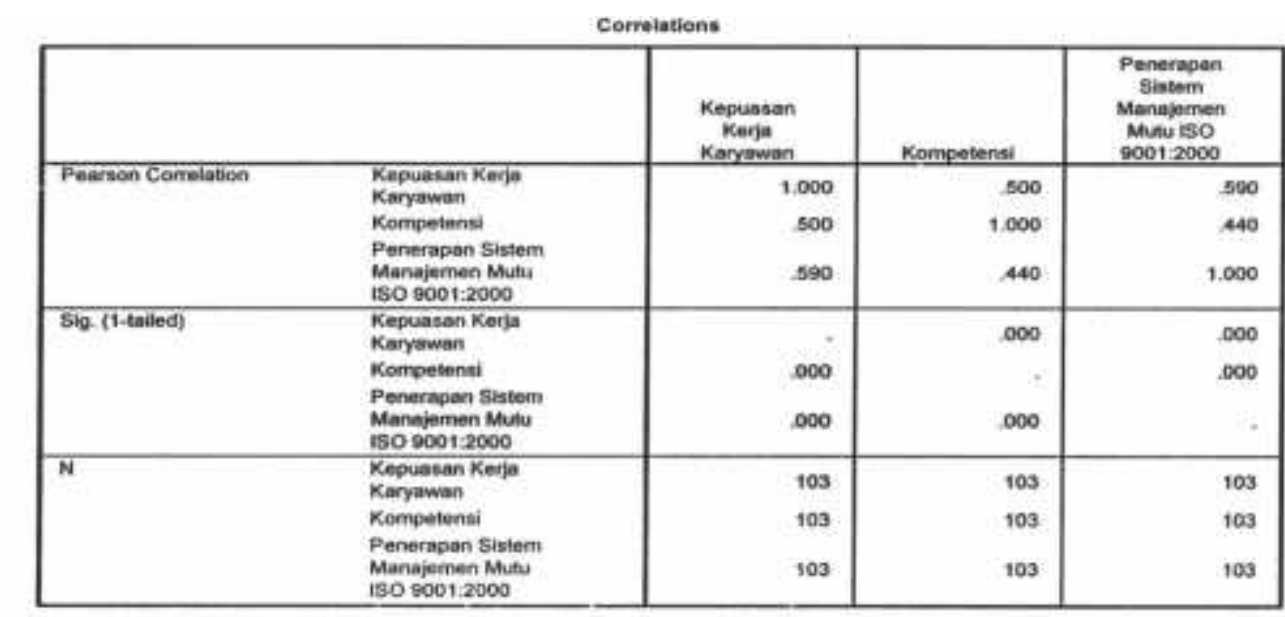

Sumber : Data Diolah

Tabel tersebut diatas menunjukkan bahwa angka korelasi $\left(\mathrm{r}_{\mathrm{y} 1}\right)$ antara Kompetensi $\left(\mathrm{X}_{1}\right)$ dengan Kepuasan Kerja Karyawan (Y) adalah 0,500. Angka tersebut menunjukkan terdapat korelasi atau hubungan positif antara Kompetensi $\left(\mathrm{X}_{1}\right)$ dengan Kepuasan Kerja Karyawan (Y) dengan tingkat kekuatan sedang. Korelasi antara variabel Kompetensi $\left(\mathrm{X}_{1}\right)$ dengan variabel Kepuasan Kerja Karyawan (Y) adalah 0,500. Dengan demikian koefisien determinasi adalah $\mathrm{r}_{\mathrm{y} 1}{ }^{2}=0,500^{2}=0,250$ atau $25 \%$. Angka koefisien determinasi tersebut 
mengandung makna bahwa 25\% dari Kepuasan Kerja Karyawan ditentukan oleh variabel Kompetensi, sedangkan $75 \%$ lainnya ditentukan oleh faktor lainnya.

Terdapat Pengaruh Penerapan Sistern Manajemen Mutu ISO 9001:2000 ( $\left.\mathbf{X}_{2}\right)$ terhadap Kepuasan Kerja Karyawan Pegawai (Y). Dengan menggunakan perhitungan SPSS dapat diperoleh hasil regresi sebagai berikut : $\mathrm{Y}=17,372+0,595 \mathrm{X}_{2}$, Angka regresi tersebut menunjukkan bahwa tanpa Penerapan Sistem Manajemen Mutu ISO 9001:2000, diperoleh angka konstanta Kepuasan Kerja Karyawan sebesar 13,326, sementara itu setiap penambahan satu satuan Penerapan Sistem Manajemen Mutu ISO 9001:2000 akan meningkatkan Kepuasan Kerja Karyawan sebesar 0,595 satuan.

Tabel 11. Persamaan Regresi $Y=13,326+0,240 X_{2}$

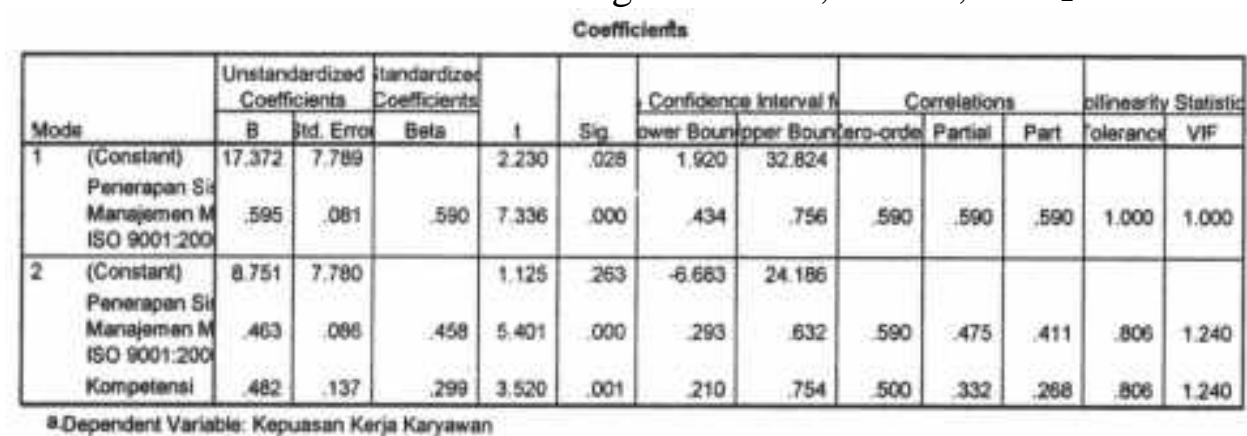

Sumber : Data Diolah

Perhitungan korelasi dengan program SPSS menghasilkan gambaran seperti tersebut pada tabel di bawah ini.

Tabel 12. Korelasi Penerapan Sistem Manajemen Mutu ISO 9001:2000 ( $\left.\mathrm{X}_{2}\right)$ Terhadap Kepuasan Kerja Karyawan (Y)

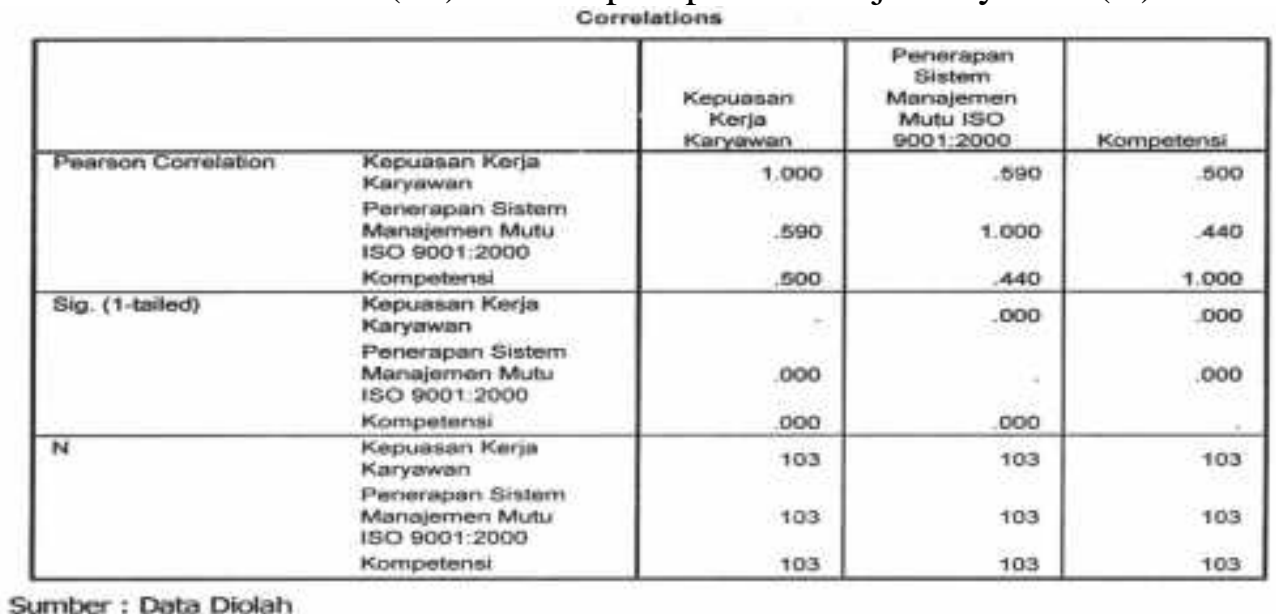

Tabel tersebut di atas menunjukkan bahwa angka korelasi $\left(\mathrm{r}_{\mathrm{y} 2}\right)$ antara Penerapan Sistem Manajemen Mutu ISO 9001:2000 ( $\left.\mathrm{X}_{2}\right)$ dengan Kepuasan Kerja Karyawan (Y) adalah 0,590. Angka tersebut menunjukkan terdapat korelasi atau hubungan positif antara Penerapan Sistem Manajemen Mutu ISO 9001:2000 ( $\left.\mathrm{X}_{2}\right)$ dengan Kepuasan Kerja Karyawan (Y) dengan tingkat hubungan sedang. Korelasi antara variabel Penerapan Sistern Manajemen Mutu ISO 9001:2000 ( $\left.\mathrm{X}_{2}\right)$ dengan variabel Kepuasan Kerja Karyawan 
(Y) adalah 0,590. Dengan demikian koefisien determinasi adalah $\mathrm{r}_{\mathrm{y} 2}{ }^{2}=0,590^{2}=0,348$ atau $34,8 \%$.

Terdapat pengaruh Kompetensi $\left(\mathrm{X}_{1}\right)$ dan Penerapan Sistem Manajemen Mutu ISO 9001:2000 $\left(\mathrm{X}_{2}\right)$ secara bersama-sama terhadap Kepuasan Kerja Karyawan Pegawai (Y). Dengan menggunakan perhitungan SPSS dapat diperoleh hasil regresi sebagai berikut: $\mathrm{Y}=8,751+0,482 \mathrm{X}_{1}+0,463 \mathrm{X}_{2}$ Angka regresi tersebut menunjukkan bahwa tanpa Kompetensi dan Penerapan Sistem Manajemen Mutu ISO 9001:2000, diperoleh angka konstanta Kepuasan Kerja Karyawan sebesar 8,751.

Tabel 13. Persamaan Regresi Berganda

$$
\mathrm{Y}=8,751+0,482 \mathrm{X}_{1}+0,463 \mathrm{X}_{2}
$$

Coefficlerts

\begin{tabular}{|c|c|c|c|c|c|c|c|c|c|c|c|c|c|}
\hline \multirow[b]{2}{*}{ Modi } & & \multicolumn{3}{|c|}{\begin{tabular}{|l|} 
Instandardized andardize \\
Coefficients Coefficient:
\end{tabular}} & \multirow[b]{2}{*}{1} & \multirow[b]{2}{*}{$\mathrm{Siz}$} & \multicolumn{2}{|c|}{ Confidence Intervai } & \multicolumn{3}{|c|}{ Correlations } & \multicolumn{2}{|c|}{ Iinearity Statis! } \\
\hline & & B & tod. Erro & Beta & & & wer Bour & pper Boun & fero-ord & Partial & Part & olerand & VIF \\
\hline \multirow[t]{4}{*}{1} & (Constant) & 8.751 & 7.780 & & 1,125 & 263 & -6.683 & 24.186 & & & & & \\
\hline & Kompetensi & .482 & .137 & 290 & 3,520 & .001 & .210 & .754 & .500 & .332 & 288 & .806 & 1.240 \\
\hline & Penerapan & & & & & & & & & & & & \\
\hline & $\begin{array}{l}\text { Manajemen } \\
\text { ISO 9001:2C }\end{array}$ & 463 & .086 & 458 & 5.401 & .000 & .299 & .632 & .590 & .475 & 411 & .806 & 1.240 \\
\hline
\end{tabular}

abependent Variabie: Kepuasan Kerja Karyawan

\section{Sumber : Data Diolah}

Perhitungan korelasi berganda dengan program SPSS menghasilkan gambaran seperti tersebut pada tabel dibawah ini.

Tabel 14. Korelasi Berganda Kompetensi $\left(\mathrm{X}_{1}\right)$, dan Penerapan Sistem Manajemen Mutu ISO 9000 : $2000\left(\mathbf{X}_{2}\right)$ Terhadap Kepuasan Kerja Karyawan (Y)

Model Summary

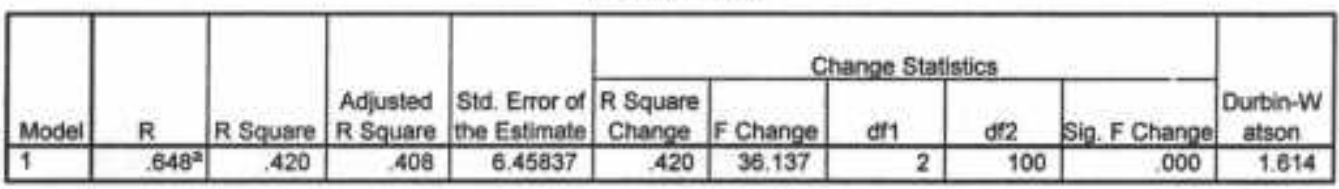

a. Predictors: (Constant), Penerapan Sistem Manajemen Mutu iSO \$001:2000, Kompetensi

b. Dependent Variable: Kepuasan Kerja Karyawan

\section{Sumber : Data Diolah}

Tabel tersebut di atas menunjukkan bahwa angka korelasi antara Kompelensi $\left(\mathrm{X}_{1}\right)$ dan Penerapan sistem Manajemen Mutu ISO 9001:2000 ( $\left.\mathrm{X}_{2}\right)$ secara bersama dengan Kepuasan Kerja Karyawan (Y) adalah $\mathrm{Ry}_{1,2}=0,648$. Angka tersebut menunjukkan terdapat korelasi atau hubungan positif antara Kompetensi $\left(\mathrm{X}_{1}\right)$, dan Penerapan Sistem Manajemen Mutu ISO 9001:2000 ( $\left.\mathrm{X}_{2}\right)$ dengan Kepuasan Kerja Karyawan(Y) dengan tingkat hubungan kuat.

Korelasi berganda antara variabel Kompetensi $\left(\mathrm{X}_{1}\right)$, dan Penerapan Sistem Manajemen Mutu ISO 9001 : $2000\left(\mathrm{X}_{2}\right)$ secara bersama-sama terhadap variabel Kepuasan Kerja Karyawan $(\mathrm{Y})$ adalah 0,648 . Dengan demikian koefisien determinasi adalah $\mathrm{R}^{2}=$ $0,648^{2}=0,420$ atau $42 \%$. Angka koefisien determinasi tersebut mengandung makna bahwa $42 \%$ dari Kepuasan Kerja Karyawan ditentukan oleh variabel Kompetensi dan 
Penerapan Sistem Manajemen Mutu ISO 9001 : 2000 secara bersama-sama, sedangkan sisanya $58 \%$ lainnya ditentukan oleh faktor lain.

\section{PENUTUP}

Simpun. Berdasarkan hasil pengujian hipotesis, dapat disampaikan kesimpulan sebagai berikut: Pertama, kecendrungan pengaruh variable Kompetensi terhadap variabel Kepuasan Kerja Karyawan, ditunjukkan oleh persamaan regresi linear sederhana $\mathrm{Y}=$ $38,611+0,807 \mathrm{X}_{1}$, dengan memiliki tingkat keberartian sedang dan linear. Persamaan regresi linear sederhana tersebut menyatakan bahwa setiap kenaikan 1 unit variabel Kornpetensi akan mempengaruhi kenaikan variabel Kepuasan Kerja Karyawan sebesar 0,807 unit, pada konstanta sebesar 38,611. Terdapat hubungan positif dengan tingkat kekuatan sedang $\left(\mathrm{ryx}_{1}=0,500\right)$. Adapun kontribusi variabel Kornpetensl terhadap variabel Kepuasan Kerja Karyawan di tunjukkan oleh koefisien determinasi yaitu sebesar 25\%. Dengan demikian Kepuasan Kerja Karyawan masih dipengaruhi oleh faktor lain sebesar $75 \%$. Kedua, kecendrungan pengaruh variable Penerapan sistem Manajemen Mutu ISO 9001 : 2000 terhadap varlabel Kepuasan Kerja Karyawan, ditunjukkan oleh persamaan regeresi linear sedemana $\mathrm{Y}=17,372+0,59 \mathrm{SX}_{2}$ dengan memiliki tingkat keberartian sedang dan linear. Persamaan regresi linear sedertaanatersebut menyatakan bahwa setiap kenaikan 1 unit varaibel Penerapan Slstem Manajemen Mutu ISO 9001 : 2000 akan mempengaruhi kenaikan variabel Kepuasan Kerja Karyawan sebesar 0,595 unit, pada konstanta sebesar 17,372. Terdapat hubungan positif dengan tingkat kekuatan yang rendah/lemah $\left(\mathrm{ryx}_{2}=0,590\right)$. Adapun kontribusi variabel Penerapan Sistem Manajemen Mutu ISO 9001 : 2000 terhadap variabel Kepuasan Kerja Karyawan ditunjukkan oleh koefisien determinasi yaitu sebesar 34,8\%. Dengan demikian Kepuasan Kerja Karyawan masih dipengaruhi oleh faktor lain sebesar 65,2\%.

Ketiga, kecendrungan pengaruh variabel Kompetensi dan Penerapan Sistem Manajemen Mutu ISO 9001 : 2000 secara bersama-sama terhadap variabel Kepuasan Kerja Karyawan, ditunjukkan oleh persamaan regresi linear berganda $\mathrm{Y}=8,751+0.482 \mathrm{X}_{1}+$ $0,463 \mathrm{X}_{2}$ dengan memilikl tingkat keberartian kuat. Persamaan regresi linear berganda tersebut menyatakan bahwa setiap kenaikan 1 unit/skor variabel Kompetensi dan variabel Penerapan Sistem Manajemen Mutu ISO 9001 : 2000 akan mempngaruhl kenaikan variabel Kepuasan Kerja Karyawan sebesar 0,482 dan 0,463 unit/skor, pada konstanta sebesar 8,751. Terdapat hubungan berganda positif dengan tingkat kekuatan sedang $\left(\operatorname{Ryx}_{1} \mathrm{x}_{2}=0,648\right)$. Adapun kontribusi variabel Kompetensi dan Penerapan Sistem Manajemen Mutu ISO 9001 : 2000 secara bersama-sama terhadap Kepuasan Kerja Karyawan yang rendah ditunjukkan oleh koefisien determinasi, yaltu hanya sebesar $42 \%$. Dengan demikian masih terdapat 58\% faktor lain, diluar Kompetensi dan Penerapan Sistem Manajemen Mutu ISO 9001 : 2000 yang mempengaruhi variabel Kepuasan Kerja Karyawan diantaranya adalah kompensasi dan situasi atau suasana kerja.

Lmplikasl. Dengan melihat kesimpulan dari penelitian ini, terbukti bahwa Kepuasan Kerja Karyawan dapat dipengaruhi atau ditentukan oleh Kompetensi dan Penerapan Sistem Manajemen Mutu ISO 9001 : 2000, dampak yang diperoleh dari penelitian tersebut, terdapat beberapa implikasi pada Universtias Mercu Buana di Jakarta, adalah sebagai berikut : Pertama, bahwa Kepuasan Kerja Karyawan Universtias Mercu Buana di 
Jakarta dapat ditingkatkan, apabila tidak hanya mengandalkan pada variabel Kompetensi dan Penerapan Sistem Manajemen Mutu ISO 9001 : 2000 terutama apabila dilakukan secara sendiri-sendiri maupun dikontrol oleh variabel lain yang terdapat dalam penelitian ini yaitu variable Kompetensi dan Penerapan Sistem Manajemen Mutu ISO 9001 : 2000.

Kedua, Kompetensi yang kontribusinya sedang hanya sebesar 25\% terhadap Kepuasan Kerja Karyawan dapat mengakibatkan terjadinya penurunan tingkat Kepuasan Kerja Karyawan terhadap hasil tugas yang diembannya karena penlngkatan Kepuasan Kerja Karyawan yang didukung oleh Kompetensl akan dapat memberikan hasil kerja yang optimal.

Ketiga, Penerapan Sistem Manajemen Mutu ISO 9001 : 2000 yang kontribusinya sedang sebesar 34,8\% terhadap Kepuasan Kerja Karyawan masih dapat menurunkan tingkat Kepuasan Kerja Karyawan. Dengan kontribusi Penerapan Sistem Manajemen Mutu ISO 9001 : 2000 terhadap kepuasan kerja karyawan yang belum optimal masih dapat menurunkan tingkat kepuasan kerja karyawan.

\section{DAFTAR RUJUKAN}

Basuki, Johannes., (1997) Budaya Organisasi, Konsep dan Terapan, Jakarta: Yayasan Pembina Manajemen.

Brotoharsojo, Jiwo Wungu Hartanto., (2003) Merit System, Jakarta, Raja Grafindo Persada, Cetakan Pertama.

Cherrington, David J., (1989) Organizational Behavior: The Management of Individual and Organization Performance, Massachusets USA: Allyn and Balon.

Crunny, CJ., (1992) Job Satisfaction How People Feel Their Jobs and How it Affects Their Performance, Lofquist and Davis.

David, Keith, \& Newstrom W. John., (2002) Human Behavior at Work: Organlzational Behavior, McGraw Hill, Intemational, New York.

Gaspersz, Vincent, (2005) ISO 9001:2000 and Continual Quality Improvement, Penerbit Gramedia Pustaka Utama, Cetakan ke empat.

Gibson, Ivancevich dan Donnely., (1984) Organisasi dan Manajemen, Jakarta: Erlangga, Edisi Ke Empat.

H. Hardiwihardjo, Bambang, dan Wibisono, Sulistianingsih., (1996) Memasuki Pasar International Dengan ISO 9000 Sistem Manajemen Mutu, Jakarta: Ghalia Indonesia.

H. Malayu S.P Hasibuan., (2003) Manajemen Sumber Daya Manusia, Edisi Revisi, Penerblt PT. Bumi Aksara.

Hamalik, Oemar., (1993) Psikologi Manajemen, Jakarta: Trigenda Karya.

Handoko, Hani T., (1997) Manajemen Personalia dan Sumber Daya Manusia. Edisi ke dua, Yogyakarta: BPFE.

Hasibuan, Malayu SP., (2006) Manajemen Sumber Daya Manusia, Edisi Revisi Cetakan ke 8, Bumi Aksara, Jakarta.

Huyink, DS and Westotover.C., ISO 9000 Motivating The People, Marketing Press. Achieving Registrations.

lvancevich, John M., (2002) Human Resourc Management, McGraw-Hill Irwin, New York. 
Justine T. Sirait., (2006) Memahami Aspek-Aspek Pengelolaan Sumber Daya Manusia dalam Organisasi, Penerblt Graslndo.

Luthan, Fred, (2002) Organization Behavior, New York, McGraw-Hill.

Luthan, Fred., (1997) Organizational Behavior, New York:McGraw Hill.

Mangkunegara, AA .Anwar Prabu., (2004) Evaluasi Kinetja SDM, Rafika Aditama Bandung, 2004.

Mangkunegara, AA. Anwar Prabu., (2002) Manajemen Sumber Daya Manusia Perusahaan, Bandung: Remaja Rosda Karya, Cetakan Ke Empat.

Mathis, Robert L, dan Jackson, Jhon H., (2001) Manajemen Sumber Daya Manusia, Jakarta, Salemba Empat.

Notoatmojo, Soekidjo., (2003) Pengembangan Sumber Daya Manusia, Jakarta: Kinerka Opta, Cetakan ke tiga.

Panggabean, Mutiara S.,(2004) Manajemen Sumber Daya Manusia, Ghalia Indonesia, Jakarta.

Prahalad dan Hamel., (1990) Characteristics of Organization Competence, Harvard Bussiness Review, 93-94.

R. Phalad., (2007) Competency Management. Penerbit PPM Anggota IKAPI.

Robbin, Stephen P., (2003) Organizational Behavior, Ten Edition, Edisi Kesepuluh, Pretince-Hall lnternational Inc, New Jersey, 2003.

Robbin, Stephen P, (2001) Perilaku Organisasi, Alih Bahasa: Hardiana Pujaatmaka, Jakarta: Prenhalindo.

Sharma, Radha R., (2002) 360 Feed Back, Competency Mapping and Assessment Center, New Delhi: Tata McGraw.Hill.

Suardi, Rudi., (2004) Sistem Manajemen Mutu ISO 9000:2000, Penerapannya Untuk Mencapal TQM, Jakarta: Penerbit PPM.

Sugiyono., (2006) Metode Penelitian Bisnis, Ikatan Penerbit Indonesia (IKAPI)

Sultan Syah, (2004) Mahendra. Manajemen Proyek-Kiat sukses Mengelola Proyek, Jakarta: Gramedia.

Wibowo, (2007) Manajemen Kinerja, Penerbit. Raja Graflndo Persada, Jakarta. 